\title{
THE SUPERVISION OF GUILTY PLEAS BY THE COURT OF APPEAL OF ENGLAND AND WALES - WORKABLE RELATIONSHIPS AND TRAGIC CHOICES
}

\begin{abstract}
The judgments of criminal appeal courts are an example of Calabresi and Bobbitt's concept of 'tragic choice'. Judges justify convictions by reference to the values which they attribute to criminal procedures: fairness, truth and rights, rather than the full range of considerations which have influenced the introduction of those procedures: cost, efficiency, crime control, public perceptions of crime, etc. The difficulties facing the Court of Appeal in justifying convictions by juries after a full trial are multiplied in the case of convictions following guilty pleas. A procedure which on its face is less capable of identifying guilt than a trial, has to be defended on the basis that it is overwhelmingly more capable of identifying guilt (or so fair as to justify disregarding the possibility of innocence). Recent changes to the plea system restricting maximum sentence discounts to pleas made at the earliest opportunity further distance guilty pleas from the protections afforded by trial, and compound the difficulties in justifying these convictions as 'safe'. With guilty pleas we have reached a situation where the Court of Appeal seems unable to provide a remedy for miscarriages, but instead, like the judges of the 19th century opposing the creation of the Criminal Court of Appeal, claims the procedure is so safe that there is little or no need for review, even in cases of procedural irregularity (short of abuse of process) or new evidence (short of exoneration).
\end{abstract}

\section{INTRODUCTION}

I think that the Complaints of the present Mode of administering the Criminal Law have little Foundation, for the Cases in which the Innocent are improperly convicted are extremely rare; some, no doubt, there are; and I consider it

\footnotetext{
*Richard Nobles, Professor of Law, Queen Mary University of London. E-mail: R.Nobles@qmul.ac.uk.

**David Schiff, Emeritus Professor of Law, Queen Mary University of London. E-mail: D.Schiff@qmul.ac.uk.
} 
impossible in any human System in administering Justice to avoid such Misfortunes occasionally. (Baron Parke's evidence in 1848 to a Select Committee of the House of Lords on a Criminal Law Administration Amendment Bill). ${ }^{1}$

Is Baron Parke's sanguinity about the improbability of miscarriages of justice in the 19th century merely a matter of historical interest, or does it find echoes in judicial attitudes towards the safety of convictions today? And if such echoes exist, does this point to the presence, in our criminal justice system, of factors that transcend historical change? In this article we explore the theme of judicial reluctance towards undoing convictions in the context of the everincreasing reliance on guilty pleas as a mechanism by which those convictions are achieved.

\section{OVERVIEW}

Our exploration proceeds through four stages. In Part One we draw on arguments, previously made by us and mirrored in the writings of many others, as to the reasons why appeal court judges necessarily show deference to the trial court practices which they formally supervise, and the difficulties which this creates for them when it comes to identifying miscarriages of justice. In the second part, we describe the English criminal justice system's current dependence on convictions obtained through guilty pleas, and the constraints placed on the possibilities to appeal those convictions. In the third part, we consider the justifications given for these restricted rights of appeal and demonstrate that they lack both plausibility and coherence. They are, we will claim, modern examples of what, from an external perspective appear as a wilful refusal to embrace the real chances for miscarriages of justice to arise from flawed criminal justice procedures. In the last section, we discuss the prospects for changes which might alleviate the need for our senior judiciary to continue to deny the obvious risk of wrongful (both in the sense of unfair and factually incorrect) convictions when considering appeals from convictions obtained following guilty pleas.

\footnotetext{
${ }^{1}$ Quoted in A.H. Manchester, Sources of English Legal History: Law, History, and Society in England and Wales 1750-1950 (London: Butterworths, 1984), 179. Baron Parke (later Lord Wensleydale) was a senior judge sitting as a Law Lord until his death in 1868. Opposition by senior judicial figures was significant in preventing the setting up of a Criminal Court of Appeal during the 19th century in which some 31 Bills trying to do so failed, before one eventually succeeded in 1907.
} 


\section{PART ONE: THE NEED FOR APPEAL COURTS TO EXHIBIT DEFERENCE TOWARDS THE PROCEDURES WHICH THEY SUPERVISE}

The reluctance of the English judiciary to re-examine convictions arising from trial by jury has a long history, dating back to well before the passing of the Criminal Appeal Act 1907 and the creation of the Criminal Court of Appeal, the first court to be given this specific authority. ${ }^{2}$ Whilst there are many factors which have led and may well continue to lead to this reluctance, whether directed towards jury trial or other means by which convictions are achieved, one of the central reasons is common to any system of appeals - the need for a workable relationship between institutions making decisions at first instance, and the bodies that have authority for correcting their errors. ${ }^{3}$ In the context of criminal appeals, the Court of Appeal has to be able to identify errors within the criminal justice system, without undermining the ability of first instance criminal courts to administer the number of cases that are being steered towards them through arrests, charges and other pre-trial procedures. As part of this task, it needs to avoid overwhelming itself by generating more appeals than it, or other courts acting in their capacity as appeal courts, can hope to process or can only process with an ever-increasing backlog of undecided cases.

A workable relationship between the appeal and trial courts has implications for what the appeal courts can identify as errors. For example, if an appeal court treats every case where it would reach a different verdict on the evidence as an error, then there does not need to be anything wrong with trial procedures for an appeal to be

\footnotetext{
${ }^{2}$ See R. Pattenden, English Criminal Appeals 1844-1994 (Oxford: Oxford University Press, 1996) especially ch 1 'The Making of the Court of Criminal Appeal' and ch 2 'The Court of Appeal, Criminal Division: An Overview'; R. Nobles and D. Schiff Understanding Miscarriages of Justice (Oxford: Oxford University Press, 2000) ch 3 'Remedying miscarriages of justice: the history of the Court of Criminal Appeal', esp 41-55.

${ }^{3}$ As background to some of wide-ranging issues involved, see: M. Shapiro, 'Appeal' (1980) Law \& Society Review 629; R. Nobles and D. Schiff, 'The Right to Appeal and Workable Systems of Justice' (2002) 65 Modern Law Review 676; R. Nobles and D. Schiff, 'The Criminal Cases Review Commission: establishing a workable relationship with the Court of Appeal' [2005] Criminal Law Review 173; R. Pattenden, 'The standards of review for mistake of fact in the Court of Appeal, (Criminal Division)' [2009] Criminal Law Review 16; M. Elliott and R. Thomas, 'Tribunal Justice and Proportionate Dispute Resolution' [2012] Cambridge Law Journal 297.
} 
possible: all verdicts are open to a de novo consideration. Since its creation, the Criminal Court of Appeal (now Court of Appeal (Criminal Division)) has strongly resisted such a role, ${ }^{4}$ limiting itself to the review of procedures pre-trial and trial, and adamantly (subject to its interpretation of a few so-called 'lurking doubt' ${ }^{5}$ or otherwise exceptional cases) only reappraising verdicts where it finds procedural errors or compelling new evidence. This resistance has been the subject of strong criticism, with the Court of Appeal regularly, throughout its history, accused of showing 'undue deference' to the verdicts of juries. ${ }^{6}$ There is a substantial academic literature dealing with this aspect of the Court's performance, and with the work of the Criminal Cases Review Commission ('CCRC'), the body introduced to redress a variety of perceived failures, including that of the Court of Appeal as a mechanism for the rectification of miscarriages of justice. ${ }^{7}$ But despite whatever may constitute 'undue' deference, there is an inescapable need for the Court of Appeal to show some level of deference towards the bodies and procedures which it supervises.

As the body (together with other bodies sitting as lower appeal courts) which decides on which convictions should be quashed, the Court of Appeal also has responsibility for deciding on the converse which convictions should stand. This unavoidably involves an exercise in justification. Every rejected appeal or application for leave to

\footnotetext{
${ }^{4}$ Stated clearly by Lord Tucker in the Privy Council case of Aladesuru v R [1956] AC 49 , at $54-5$. ' $\ldots$ it has long been established that the appeal is not by way of rehearing as in civil cases on appeals from a judge sitting alone, but is a limited appeal which precludes the court from reviewing the evidence and making its own valuation thereof.'

${ }^{5}$ See L.H. Leigh, 'Lurking doubt and the safety of convictions' [2006] Criminal Law Review 809; and succinctly, R. Grist, 'Lurking doubts remain' Criminal Law \& Justice Weekly 2012, 176(22) 313-14. Success will only occur in 'exceptional' cases', see $R$ v Pope (John Randall) [2012] EWCA Crim 2241.

${ }^{6}$ See, for a clear example, The Report of the Royal Commission on Criminal Justice, Cm 2263 (London, HMSO, 1993) ch 10, para 3; also S. Roberts, 'Fresh evidence and factual innocence in the Criminal Division of the Court of Appeal' [2017] Journal of Criminal Law 303, esp 304-5, and n 8.

${ }^{7}$ M. Zander, 'The Criminal Cases Review Commission, the Court of Appeal and jury decisions - a better way forward', Criminal Law \& Justice Weekly 2015, 179(4), 179(12), 179(7); M. Zander, 'The Justice Select Committee's report on the CCRC where do we go from here?' [2015] Criminal Law Review 473; H Quirk, 'Identifying Miscarriages of Justice: Why Innocence in the UK Is Not the Answer' (2007) 70 Modern Law Review 759; S. Roberts and L. Weathered. 'Assisting the Factually Innocent: 'The Contradictions and Compatibility of Innocence Projects and the Criminal Cases Review Commission' (2009) Oxford Journal of Legal Studies 43.
} 
appeal is a decision involving the claim that the procedures that led to the conviction were 'good' or at least 'good enough'. So, for example, whilst there are any number of ways in which a trial before a jury may go wrong, it is not open to the Court of Appeal to express doubts on the ability of jury trial, as an institution, to reach correct conclusions as to the guilt of those that they convict. The 'good enough' quality of the jury as a fact-finding body is not an opinion reached on the basis of social scientific evidence, ${ }^{8}$ it is something reiterated, within the criminal justice system, explicitly or implicitly, with each rejected appeal against a jury verdict. Not only must the Court acknowledge the general suitability of juries as fact-finding bodies, it must also resist grounds of appeal which would undermine the ability of juries to execute their fact-finding function. So, for example, 'normally' allowing appeals on the basis of evidence not used, or arguments not made, would seriously weaken the ability of juries to determine guilt, as every trial involves some unused evidence and some discarded arguments. ${ }^{9}$

The statutory powers allocated to the Court of Appeal give the Court an almost unlimited power to declare any conviction unsafe. ${ }^{10}$ This formally unlimited supervisory power has to be seen in the context of a system whose features lie largely outside of the Court's control. It does not, for example, establish the levels of legal aid, or the funding available to the police or the Crown Prosecution Service ('CPS') for the investigation and prosecution of crime, or even the

\footnotetext{
${ }^{8}$ This is not to deny that such evidence is available. Cheryl Thomas' analysis of jury verdicts, for example, offers reassuring evidence that they are not biased against black defendants, that they convict at a higher rate where offences involve the most direct evidence of guilt, and at lower rates when the offence requires a judgement on the intentions which accompany the relevant acts; but that less than a majority of juries fully understand the judges' legal directions: see her 'Ethnicity and the Fairness of Jury Trials in England and Wales 2006-2014' [2017] Criminal Law Review 860; and 'Are Juries Fair?' (UK Ministry of Justice Research Series, 01/10, 2010). Whilst this evidence is indeed generally reassuring, it is not the source for judicial deference to jury verdicts.

${ }^{9}$ For a brief discussion of this issue, in the context of expert evidence, see W.E. O'Brian, 'Fresh Expert Evidence in CCRC Cases' (2011) 22 King's Law Journal 1, esp $3-7$.

${ }^{10}$ The relevant legislation is the Criminal Appeal Act 1968, section 2, as amended by the Criminal Appeal Act 1995, section 2, which legislation does not define what constitutes 'unsafe', except negatively. For example, the Court may not consider an appeal based on the claim that a defendant should have been entitled to elect for summary trial but was denied this right due to an erroneous over-valuing of the property involved: 1968 Act, s. 1(3).
} 
budgets allocated to itself or the courts which it supervises. And whilst much criminal procedure is within judicial control, being either a creature of the common law, or rules announced by the Court itself, or by bodies staffed by judges, ${ }^{11}$ substantial elements are the result of statute and policy priorities, over which judges have limited influence. ${ }^{12}$ The criminal justice system is constructed in response to considerations of cost and efficiency, as well as more obvious political agendas such as social control, and many other indeterminable factors, such as the perceived need to respond to fears of crime expressed within the mass media. ${ }^{13}$ But, when attempting to justify convictions as 'safe' it is not open to the Court of Appeal to draw on these kinds of consideration in deciding that particular defendants, who may be innocent of the crimes of which they are charged, should nevertheless continue to be punished. The Court operates through a discourse which assumes that convictions obtained in accordance with defendants' rights will ordinarily establish 'safe' convictions in nearly all cases, limiting itself to quashing convictions obtained where there has been a breach of those rights, or where new evidence has emerged that was not available at the trial, and only exceptionally in other 'lurking doubt' cases. The need to assume that the criminal justice process ordinarily produces safe convictions means that the Court of Appeal's supervisory role involves a strong element of deference. In

${ }^{11}$ For example, judges make up eight of the fourteen members of the Sentencing Council: https://www.sentencingcouncil.org.uk/about-us/council-members/.The Criminal Procedure Rule Committee consists of the Lord Chief Justice of England and Wales and 17 people appointed by the Lord Chief Justice and the Lord Chancellor under section 70 of the Courts Act 2003 https:/www.gov.uk/government/organisa tions/criminal-procedure-rule-committee/about\#membership.

${ }^{12}$ For an example of judges struggling with statutory procedural requirements which clash with their concepts of a fair trial, see $R v B$ [2003] EWCA Crim 319 at paras 26 and 27 - historic sex abuse conviction based on the complainant's uncorroborated testimony, following statutory removal of the requirement for corroboration - overturned on the basis of 'a residual discretion to set aside a conviction if we feel it is unsafe or unfair to allow it to stand. .. even where the trial process itself cannot be faulted.'

${ }^{13}$ See R. Reiner, S. Livingstone and J. Allen, 'From law and order to lynch mobs: crime news since the Second World War, in P. Mason (ed.), Criminal Visions: Media Representations of Crime and Justice (Devon: Willan Publishing, 2003), ch 1. High profile crimes 'signal' the problems within society that require reaction, see M. Innes, "Signal crimes", detective work, mass media and constructing collective memory", also in P. Mason (ed.) ch 3. For a classic study of criminal justice responding to media created perceptions of crisis, see $\mathrm{S}$. Hall et al, Policing the Crisis: Mugging, the State, and Law and Order (London: Macmillan, 1978). 
previous publications we have described the Court of Appeal's need to justify a system of trial constructed by reference to factors outside its control and for reasons that it cannot articulate, as an example of tragic choice. ${ }^{14}$ Choices are tragic here arising from the difficulties of upholding values associated with justice - the ability of the criminal process to establish the fact of defendants' guilt through fair procedures - in the face of institutions whose design is heavily influenced by other values such as cost and efficiency.

\section{PART TWO: THE GUILTY PLEA REGIME AND RESTRICTIONS ON THE ABILITY TO APPEAL}

The need for deference, and the difficulties of justifying it, are heightened when one refocuses to consider the relationship between the Court of Appeal and convictions achieved through guilty pleas. At present, around $91 \%$ of the convictions obtained by the CPS are the result of guilty pleas. The figure for convictions obtained via plea in the Crown Court alone is $88.38 \%{ }^{15}$ Thus, we have a large dependence on guilty pleas comparable to that in the USA, a level which led their Supreme Court to observe that pleas, not trials 'is the

\footnotetext{
${ }^{14}$ We have, in particular, analysed the responsibility and role of the Court of Appeal by drawing on G. Calabresi and P. Bobbitt's concept of tragic choice in their book Tragic Choices (New York: W.W.Norton, 1978). Tragic choice describes the situation when chosen first order institutional arrangements have to be defended at a secondary level without acknowledging the inherent sacrifice of values in those earlier choices. See R. Nobles and D. Schiff, 'The Never-Ending Story: Disguising Tragic Choices in Criminal Justice' (1997) 60 Modern Law Review 293.

${ }^{15}$ In their 2018-19 annual report the CPS record convictions in $83.7 \%$ of their cases, with convictions obtained via guilty plea in $76.7 \%$ of cases. Guilty pleas were therefore $91.64 \%$ of total convictions. See Crown Prosecution Service Annual Report and Accounts 2018-9, HC 2286, p. 7. A breakdown of convictions obtained in the Magistrates' and the Crown Courts over the three financial years 2016-7, 2017-8, and 2018-9 is provided at pages 22 and 25. Ignoring convictions obtained in absence (mostly minor traffic offences dealt with in the absence of the defendant) the percentage of convictions obtained through guilty pleas over these three years in each court were: Magistrates' Courts: 93.21\%, 92.7\%, 93.56\%; Crown Courts: 88.79\%, $88.68 \%, 88.38 \%$.
} 
criminal justice system'. ${ }^{16}$ As in the United States, defendants are offered inducements to plead guilty, in the form of lower sentences than would occur if they were convicted at trial. These reductions occur in three ways: through an automatic reduction of up to a third off the sentence that would be the appropriate starting point if conviction had followed trial; through the prosecution accepting a guilty plea to a lesser charge and not pursuing the more serious charge or charges; ${ }^{17}$ by the prosecution agreeing to the conviction being based on a less serious version of the facts than might otherwise be established at trial. ${ }^{18}$ Contrary

\footnotetext{
${ }^{16}$ See Lafler v Cooper 566 U.S. Rep. 156 (2012) and Missouri v Frye 566 U.S. 134 (2012) decided on the same day and approving this statement taken from R. Scott and W. Stuntz, 'Plea Bargaining as Contract' (1992) 101 Yale Law Journal 1909, at 1912. The Supreme Court made this observation in light of $97 \%$ of federal convictions and $94 \%$ of state convictions being the result of guilty pleas. The manner in which our guilty plea system resembles that in the US is not limited to numbers - see the common features identified by Lord Brown in McKinnon v US (2008) UKHL 59, para 34. Even in the US the change from an informal plea-bargaining system to the formal one of today is of recent origin: see D.J. Newman, Conviction: The Determination of Guilt or Innocence Without Trial (Boston: Little, Brown and Co, 1966).

${ }^{17}$ The Code for Crown Prosecutors 2018 states that the prosecution, when considering whether to accept a guilty plea, must not do so 'just because it is convenient', and that they must ensure that 'the court is able to pass a sentence that matches the seriousness of the offending, especially where there are aggravating features.' CPS code of guidance, 2018, paras 9.4 and 9.2. It is difficult to see this as anything more than a directive not to abandon more serious charges where defendants have no serious prospect of acquittal. If there is any doubt that the prosecution will succeed, then it is not simply a matter of 'convenience' to accept a lesser charge. The 'evidence' test for charging identifies the 'space' for prosecutors to accept pleas to lesser charges. Charging only requires judgement that a conviction is 'more likely than not', whilst a court is required to be 'sure that the defendant is guilty'. (para 4.7). https:// www.CPS.gov.uk/publication/code-crown-prosecutors.

${ }^{18}$ In the U.S. in 2001 (the last year when the relevant data was collected and published) the average length of incarnation for defendants who pleaded guilty in the Federal courts was $61.6 \%$ less than the sentence imposed on those who were convicted at trial. (See Compendium of Federal Justice Statistics, Table 5.3: https://www.bjs. gov/index.cfm?ty $=$ pbdetail\&iid $=599$. This was despite the fact that the Federal Sen tencing guidelines recommend on average only a $35 \%$ maximum reduction in sentence for accepting responsibility. (See S. Bibas, 'Plea Bargaining outside the Shadow of Trial' (2004) 117 Harvard Law Review 2463, at 2488-9.) Bargaining over facts, and pleading to charges with lower sentences, may account for the additional $26 \%$. To know whether fact and charge negotiations allow the CPS to offer a similar level of discount to US prosecutors, data would have to be collected on the custodial sentences imposed on persons convicted by plea and after trial, and the averages compared. To our knowledge, this data is not available. For our purposes, the important point is that the English criminal justice system's dependence on guilty pleas is comparable to the U.
} 
to former orthodoxy, ${ }^{19}$ our judiciary can now confirm, on request, what sentence would be imposed if the defendant pleaded guilty and, in a break from the adversarial tradition, may even raise the issue of a guilty plea in open court where it appears clear to them that a guilty plea should have been considered by the defendant. $^{20}$ They may not however inform defendants of the sentences that they can expect if they continue to plead not guilty and are convicted at trial. ${ }^{21}$ The scope and need for circuit judges to become directly involved in this process has been reduced by the recent standardisation of reduction of sentence attributable to the plea itself, and by the introduction of a requirement that the maximum one third sentence reduction will only occur if defendants plead guilty at their first appearance at the Magistrates' Court. ${ }^{22}$ The former reduces the need for individual judges to form their own views of what reduction might be justified (for example, giving less reduction where they consider the evidence of guilt overwhelming); ${ }^{23}$ the latter requires defendants who wish to

Footnote 18 continued

S., not whether the incentives offered are, on average, higher or lower. When justifying guilty plea convictions on appeal, it is not the average rate of discount which is relevant, but the actual discount offered in the individual case.

${ }^{19} R v$ Turner $[1970] 2$ Q.B. 321.

${ }^{20} R v$ Goodyear [2005] W.L.R. 2532. In Horne's view: 'asking if the defendant has been advised on discounts is a bit like asking someone to agree not to beat their partner. Since it should have already been done, the doing of it by the judge operates as pressure on the defendant'. J. Horne 'A Plea of Convenience: An Examination of the Guilty Pleas in England \& Wales' PhD thesis, University of Warwick, 2016, 218, available at: https://ccrc.gov.uk/research-at-the-ccrc/published-research-on-the-ccrc/. In the Mag istrates' Court, defendants who plead not guilty can ask for an indication as to whether, if they changed plea, they would receive a non-custodial sentence. If a positive indica tion is given, they can change their plea. J. Sprack, A Practical Approach to Criminal Procedure (Oxford, Oxford University Press, 15th edn, 2015) 113, para 8.16.

${ }^{21} R v$ Goodyear, ibid.

${ }^{22}$ Sentencing Council, Reduction in sentence for a guilty plea - first hearing on or after 1 June 2017 para 1. Available at: https://www.sentencingcouncil.org.uk/over arching-guides/crown-court/item/reduction-in-sentence-for-a-guilty-plea-first-hear ing-on-or-after-1-june-2017/. See, in particular, the flowcharts illustrating reductions.

${ }^{23}$ The guidelines, ibid., in their Key Principles, provide that: 'The strength of the evidence should not be taken into account when determining the level of reduction'. Neither should factors 'such as admissions at interview, co-operation with the investigation and demonstrations of remorse.' A residual discretion to depart from these guidelines arises only in the exceptional case, where the court is 'satisfied that it would be contrary to the interest of justice to do so.' 
obtain maximum reductions of sentence to make their pleas prior to the case appearing at the Crown Court. Unless defendants enter a guilty plea at this first appearance the reduction for guilty plea reduces from a third to a quarter (with further staged reductions down to one tenth of sentence where the guilty plea is entered on the first day of trial).

There has been a recent regularisation of the information that must be disclosed to defendants at this early stage. ${ }^{24}$ Whilst this has a number of purposes, ${ }^{25}$ one of these is to ensure that the CPS can demonstrate to defendants the strength of the prosecution case. Without this, the incentive provided by the maximum discount for pleading guilty would be undermined in failing to demonstrate to defendants that they face a strong likelihood of being convicted at trial. The level of disclosure required at this stage depends on whether defendants are in custody, and whether prosecutors can anticipate a guilty plea at the first hearing. The lowest level of disclosure applies to defendants in custody. Here disclosure is limited to a summary of the circumstances of the offence and defendants' criminal record. ${ }^{26}$

\footnotetext{
${ }^{24}$ See Initial Details of the Prosecution Case (Advance Information), set out in Sentencing Council, ibid.The ability of the CPS to meet this standard has been facilitated by a standardisation of the material which the police must provide to them at each stage of the proceedings. See National File Standard May 2015, available at: https://www.CPS.gov.uk/sites/default/files/documents/publications/dpp_guidance_ 5_annex_c.pdf.The advance information provisions do not apply to offences that are triable only summarily, but it is the policy of the CPS to provide advance provision to the defence of all proposed prosecution evidence prior to summary trial - Sprack, supra note 20, para 8.13.

25 The details must include sufficient information to allow the defendant and the court at the first hearing to take an informed view: 'i. on plea; ii. on venue for trial (if applicable); iii. for the purposes of case management; or iv. for the purposes of sentencing (including committal for sentence, if applicable).' Case progression and trial preparation in the Magistrates' Courts Criminal Practice Directions - October 2015 (including amendments up to April 2019), para 3A.4. https://www.judiciary.uk/ wp-content/uploads/2019/03/crim-pd-amendment-no-8-consolidated-mar2019.pdf.

${ }^{26}$ The Criminal Procedure Rules October 2015 as amended April 2017, para 8.3(a). https://www.justice.gov.uk/courts/procedure-rules/criminal/docs/2015/crim inal-procedure-rules-practice-directions-april-2019.pdf.
} 
But if the prosecution intends to put any other material before the court, this must first be disclosed and defendants given time to consider it prior to the decision to plead. ${ }^{27}$ The next level of advance disclosure applies to those not in custody, where the prosecution expects defendants to plead guilty. Here, prior to the first hearing at the Magistrates' Court, the CPS are required to provide the court and defendants ${ }^{28}$ with: a summary of the circumstances of the case; any account given by the defendant in interview; any written witness statement or exhibit that the prosecutor then has available and considers material to plea or to the allocation of the case for trial or sentence; a list of the defendants' criminal record, if any; any available victim impact statement. ${ }^{29}$ The highest level of advance disclosure is reserved for defendants not in custody, who are expected to plead not guilty. ${ }^{30}$ The additional disclosure required here is not directed at the plea decision (though it may affect this), but is intended to allow the issues at trial to be identified. ${ }^{31}$ The additional required information consists of details of witnesses' availability, as far as they are known; an indication of any medical or other expert evidence that the prosecution is likely to adduce in relation to a victim or the defendant; any information as to special measures, bad character or

${ }^{27}$ Ibid., para 8.4.

${ }^{28}$ Ibid., para 8.2(2).

${ }^{29}$ Ibid., para 8.3. The examples of anticipated guilty pleas provided in the national file standard demonstrate an intention to restrict these to 'open and shut' cases: 'the suspect has made a clear and unambiguous admission to the offence and has said nothing that could be used as a defence... or the suspect has made no admission but has not denied the offence or otherwise indicated it will be contested and the commission of the offence and identification of the offender can be established by reliable evidence or the suspect can be seen clearly committing the offence on a good quality visual recording.' https://www.CPS.gov.uk/legal-guidance/charging-directors-gui dance-2013-fifth-edition-may-2013-revised-arrangements (at para 17).

${ }^{30}$ The case is also likely to be allocated to a different kind of hearing and at a later date: an Early Administrative Hearing instead of a normal Early First Hearing (see Sprack, supra note 20, para 7.03).

31 'It is essential that the initial details of the prosecution case that are provided for that first hearing are sufficient to assist the court, in order to identify the real issues and to give appropriate directions for an effective trial.' Criminal Practice Directions, supra note 24, para 3A.12. 
hearsay, where applicable. ${ }^{32}$ Certain kinds of exhibit evidence are also expressly required by this stage if forming part of the prosecution case - CCTV and streamlined forensic reports. Note however that any failure to produce this last level of advance disclosure does not affect the requirement that the defendant should enter a plea at the first hearing. ${ }^{33}$

Underlying this early plea system, and the disclosure requirements that accompany it, is the assumption that decisions to plead guilty can be made on the basis of the prosecution case, as it has been developed up to this point, without any opportunity to develop the defence case. In particular, defendants have no right to inspect the material obtained by the police which does not form part of the prosecutions' case. The defence has to rely on prosecutors' duty to disclose any material which might undermine the prosecution case, ${ }^{34}$ as the defence have no statutory right to disclosure of unused material unless and until a not guilty plea is entered. There is a further assumption that this assessment can be made swiftly, as the latest date for service of the prosecution case is the morning of the day of the first hearing. ${ }^{35}$

The number of cases disposed of via guilty pleas has implications for workloads, of the Court of Appeal, if such cases are appealed from the Crown Court, and for Crown Courts when appealed from Magistrates' Courts, and if successful appeals would result in an order for a retrial. One can see how the Court of Appeal avoids this increased workload through the restrictions which it places on the grounds of appeal, and especially against convictions based on guilty pleas. In nearly all such cases, defendants can only appeal on the basis that their pleas were involuntary or equivocal. ${ }^{36}$ The need for

\footnotetext{
${ }^{32}$ Ibid.

${ }^{33}$ Ibid., para 3A.14.

${ }^{34} R$ v DPP, ex p. Lee [1999] 2 Cr. App. R. 304.

35 The Criminal Procedure Rules 2015, supra note 26, para 8.2(2)(b).

36 '[A]n appellant who wishes to challenge a plea must show either that her plea was involuntary, or equivocal (ie she pleaded guilty without understanding the nature of the charge or without intending to admit that she was guilty of what was alleged), or based on fundamentally mistaken advice'. P. Taylor (ed.), Taylor on Criminal Appeals (Oxford, Oxford University Press, 2nd edn., 2012) para 9.03.
} 
the plea to be unequivocal boils down to a requirement that the plea represents a confession to facts that constitute the offence charged. ${ }^{37}$ So, for example, where a defendant pleads guilty on the basis of alleged facts that do not constitute the offence, an appeal is allowed. ${ }^{38}$ The requirement of voluntariness adds little to this, as the courts require only that the decision to plead guilty must be the defendants' own acts, and not something that can be decided for them by their legal representatives. A plea is not rendered involuntary because defendants may have felt coerced by the greater sentence that would follow if convicted at trial. ${ }^{39}$ Indeed, if this were sufficient to render a plea involuntary, then all guilty plea convictions would be appealable. Nor does it make a difference if the pressure arises from an offer of a lower sentence or of a decision not to prosecute a family member, should defendants plead guilty. ${ }^{40}$ This too is considered by the Court of Appeal to be a 'normal' situation. ${ }^{41}$ The restricted meanings of what constitutes equivocation and voluntariness limit the legal advice required for a valid guilty plea. Defendants must understand what facts they are admitting to, and their intended factual admission must constitute the offence. ${ }^{42}$ But there is no need for defendants to have

\footnotetext{
37 'An equivocal plea is one qualified by words which, if true, indicate that the accused is in fact not guilty of the offence charged. ... Such a plea is wholly different in character - and consequence - from the plea entered here which may have been reluctant or even wrong headed but was in no sense ambiguous.' $R$ v Drew (1985) 81 Cr. App. R. 190 at 195.

${ }^{38}$ See $R v$ Malik [2018] EWCA Crim 1693, para 13.

${ }^{39}$ In McKinnon, supra note 16, an extradition case, the House of Lords were asked whether the size of the discount offered by the US authorities for a guilty plea could, in itself, be an abuse of process. Lord Brown, who gave the sole judgment, acknowledged that all sentence discounts for guilty pleas create pressure to plead guilty, but did not regard an offer to inflict a lower sentence than could be awarded after conviction at trial as either a threat or a bribe sufficient to vitiate the process. Whilst he acknowledged that some plea offers might constitute abuse, this would not be solely due to the amount of the discount, but would also depend on the way 'the case would be put' (a factor that allowed him to distinguish the Canadian Supreme Court decision in USA v Cobb [2001] 1 SCR 587, where the US prosecutor used a TV interview to draw attention to the likelihood that these defendants, if convicted after trial rather than through guilty pleas, would be incarcerated in a high security prison where there would be a high chance that they would suffer homosexual rape.

${ }^{40} R v$ Dann [2015] EWCA Crim 390.

${ }^{41} R v$ McCarthy [2015] EWCA Crim 1185, para 68.

${ }^{42}$ See Malik, supra note 38. The second successful ground of appeal was the defendant solicitor's failure to advise him that the admitted facts constituted a defence to the charge.
} 
an accurate view of the likelihood that they would be convicted if they opted for trial. ${ }^{43}$ The restricted need for advice has in turn allowed for the introduction of the requirement that defendants should plead guilty at the earliest opportunity if they are to enjoy a full (one third) reduction in sentence in return (see description above). ${ }^{44}$

The reluctance to allow appeals against guilty plea convictions is not limited to cases where defendants, without any breach of their rights, may have succumbed to the pressure to plead guilty arising from sentence discounts. The restrictions extend even to cases where defendants have suffered from breaches of their rights, that is cases which, had the convictions resulted from trials, might have led to successful appeals. The standard applied to appeals based on procedural irregularities where defendants have pleaded guilty is closely linked to the standard for a valid plea. So, for example, appeals based on erroneous judicial rulings, and appeals based on incompetent legal advice, can succeed where the effect of the ruling or advice is to lead defendants to believe that the facts they claimed occurred constituted offences when they did not, or to believe that they had no defence to the charge where one was available. ${ }^{45}$ But errors that 'merely' weaken defendants' chances of acquittal are not sufficient. This is because in the former situation, the guilty pleas cannot be read as admission to the crimes, whilst in the latter situation they can, and are. Defendants who plead guilty cannot challenge rulings by trial judges that have weakened their defences, but must plead not guilty and risk the higher sentence that will follow if convicted at trial. ${ }^{46}$ Defendants who plead guilty can still appeal an irregularity that amounts to an 'abuse of the process'. ${ }^{47}$ This is something that, if discovered prior to conviction, would have resulted in the proceedings being stayed on the basis that a fair trial was no longer possible. This is a high

\footnotetext{
${ }^{43} R$ v Caley [2012] EWCA Crim 2821, para 14.

${ }^{44}$ Sentencing Council, Reduction in sentence for a guilty plea - first hearing on or after 1 June 2017, supra note 22, para 1.

${ }^{45} R v$ Boal [1992] Q.B. 591. The defendant was wrongly advised to plead guilty for breach of relevant fire regulations when his day to day running of a shop did make him liable as 'manager' for compliance with these regulations. In the U.S. the ability to appeal against guilty plea convictions on the basis of erroneous legal advice extends to a failure to inform the defendant of the consequences that would follow from conviction, including collateral consequences such as the risk of deportation. See Padilla v Kentucky, 559 U.S. 356 (2010).

${ }^{46} R$ v Eriemo [1995] 2 Cr. App. R. 206.

${ }^{47} R v$ Asiedu [2015] 2 Cr. App. R. 8.
} 
standard so, for example, non-disclosures, however relevant to defendants' decisions to plead guilty, are unlikely to result in successful appeals in the absence of proof that the non-disclosures were occasioned by dishonesty. ${ }^{48}$

There is also a greater reluctance to allow appeals on the basis of new evidence that throws doubt on defendants' guilt. The Court of Appeal has stated that this will only exceptionally be allowed in the case of a guilty plea. ${ }^{49}$ With convictions following trial, new evidence needs to be capable of belief, provide a ground of appeal, would have been admissible at the trial and there are cogent reasons for the failure to have obtained or adduced it earlier. ${ }^{50}$ But the approach to new evidence following guilty pleas is much narrower and in practice closer to a requirement of exoneration. For example, where someone else has subsequently been convicted of the same crime, or there is incontrovertible evidence that another person committed that crime. $^{51}$

\section{PART THREE: JUSTIFYING GUILTY PLEAS}

\subsection{Justifications Offered for the Introduction and Standardisation of Discounted Sentences for Guilty Pleas}

The current system of guilty pleas is not something which was first introduced as a reform in pursuit of a particular policy. Rather, it evolved. In sharp contrast to the current situation judges, for example in the UK in the early $18^{\text {th }}$ century, discouraged guilty pleas, ${ }^{52}$ pre-

\footnotetext{
48 Ibid.

${ }^{49} R$ v Lee (1984) 79 Cr. App. R 108. The 'exceptional' circumstances of this case were: that the defendant confessed and pleaded guilty to 17 counts of arson and 26 counts of murder despite a public enquiry finding that one fire in which three persons were killed had been started accidently; his counsel had expressed disquiet over his plea at trial due to his mental condition; and the new evidence was a Sunday Times newspaper enquiry which had found that for most if not all of the fires where deaths had resulted the applicant had untainted alibis.

${ }^{50}$ Criminal Justice Act 1968 s.23(2).

${ }^{51}$ For example, $R$ v Foster [1985] Q.B. 115 - appeal was allowed when a different man was convicted of the same rape; $R v$ Halliday [2005] EWCA Crim 2230 - clear evidence accepted by the Crown that another man had committed one of the robberies, so confession and plea suspect.
}

${ }^{52}$ See J. Langbein, The Origins of Adversary Criminal Trial (Oxford: Oxford University Press, 2003), 18-20. 
ferring that a trial (often a short affair, lasting at most a few hours) ${ }^{53}$ take place. A trial enabled both judge and jury to hear defendants' responses to the evidence against them, and to judge their character, which was relevant to both the decision on their guilt, and the punishment that should follow. The willingness to accept guilty pleas developed in response to the changing nature of trials in the second part of the $18^{\text {th }}$ century. With the increasing involvement of lawyers, trial became more formal, complex, and protracted. ${ }^{54}$ This meant that guilty pleas had an advantage, in terms of saved costs, time, etc. that they had formerly lacked. Whilst some scholars attribute the growth of guilty pleas solely to the desire to avoid the increased costs of this new more expensive form of trial, others have argued that changes in the nature of prosecution are a more important factor. ${ }^{55}$ When the prosecution of crime was left to private parties, and defendants represented themselves, there was little scope for any negotiation over the charge. But with the political acceptance that crime is a government responsibility, and the introduction of state police authorities who both investigate and prosecute crimes, there was both the possibility of negotiated charges and sentences, and a political benefit from achieving them. In the United States, by the middle of the 19th century, plea bargaining had become an important tool in the armoury of public prosecutors with responsibility for tackling crime. ${ }^{56}$ In the United Kingdom, plea bargaining has until recently developed on a more informal basis. There has always been a choice, previously open to the police, now within the control of the CPS, as to which charge to pursue where overlapping charges are possible, and to prefer only the lesser charge in response to a guilty plea (as has commonly occurred with, for example, assault cases). The judiciary's first contribution to this evolutionary process was

53 J. Beattie, Policing and Punishment in London 1660-1750: Urban Crime and the Limits of Terror (Oxford: Oxford University Press, 2001), 259-260.

${ }^{54}$ By the end of the 18th century the presence of counsel had 'ushered into criminal procedure the divisions between examinations-in-chief and cross-examination and between evidence and argument, nourished the growth of the law of evidence, changed the nature of the judicial involvement in the trial, and supplemented the haphazard efforts of prisoners to defend themselves with professional advocacy.' D. Cairns, Advocacy and the Making of the Adversarial Criminal Trial 1800-1865 (Oxford: Clarendon Press, 1998), 3.

${ }^{55}$ See S. McConville and C. Mirsky, Jury Trials and Plea Bargaining: A True History (Oxford: Hart Publishing, 2005) ch.1 and works cited therein. Their book is based on a longitudinal study of prosecutions in the USA from the $19^{\text {th }}$ century.

${ }^{56} \mathrm{Ibid}$. 
their willingness to accept pleas in place of trials, and to treat ${ }^{57}$ guilty pleas as an expression of remorse justifying a reduction of sentence. ${ }^{58}$ But routinely offering sizable sentence discounts for guilty pleas has served to undermine the original 'remorse' rationale. Once there is an expectation that pleading guilty will normally lead to a sentence discount, it becomes difficult to distinguish between remorseful guilty defendants and unremorseful guilty defendants who have learned that guilty pleas will be treated as a sign of remorse and earn shorter sentences. More seriously still, significant and routine sentence reductions for guilty pleas raises the obvious risk that at least some of those pleading guilty will be unremorseful innocent defendants who plead guilty solely to reduce the expected sentence. As noted by the Royal Commission on Criminal Justice: '... it would be naïve to suppose that innocent persons never plead guilty because of the prospect of the sentence discount'. ${ }^{59}$

More recently, the desire to save costs by encouraging defendants to plead guilty at the earliest opportunity has led to sentencing guidelines that officially separate pleading guilty and expressing remorse into two independent reasons for reducing defendants' sentences. This separation prevents judges from refusing to offer the

${ }^{57}$ The choice of the word 'treat' is not accidental. Alan Manson places guilty pleas, and 'assisting the police with their enquiries', in the category of: 'Factors which have an intrinsic systemic relation to the effective operation of a criminal justice system [which] can be recognized as mitigating in order to encourage pragmatically their systemic role.' See his essay 'The Search for Principles of Mitigation: integrating cultural demands' in J. Roberts (ed.), Mitigation and Aggravation at Sentencing (Cambridge: Cambridge University Press, 2011) 40, at 42.

${ }^{58}$ It is not clear when the practice of reducing sentences for guilty pleas began, or how it was first justified. It is not mentioned in an 1877 monograph on sentencing: E.W. Cox The Principles of Punishment as Applied in the Administration of the Criminal Law, by Judges and Magistrates (London: Law Times, 1877). Cox only refers to mitigation based on the seriousness of the offence, and the character of the accused. The focus is on distinguishing the habitual from the accidental criminal: 'very little mitigation of the legal penalty be allowed to [the former] as a rule.' (159) D.A. Thomas's survey of sentencing cases in the 1960's shows that, by this time, it was routine to give sentence reductions for guilty pleas and to justify them by reference to the remorse that they represented. For example, 'Credit can be given when a person does plead guilty to the fact that that person is facing up to realities and shows some sign of repentance ...' Principles of Sentencing: The Sentencing Policy of the Court of Appeal Criminal Division (London: Heinemann, 1970) 53. If accepted as genuine expressions of remorse, guilty pleas could also be treated as significant evidence of defendants' guilt, thereby justifying strict restrictions on the right to appeal conviction following a guilty plea.

${ }^{59}$ Report of the Royal Commission on Criminal Justice, supra note 6, p. 110. 
standard discount for pleading guilty where they suspect the genuineness of the remorse accompanying the plea (for example, where defendants have insisted on their innocence up to the moment when they have been presented with overwhelming evidence of their guilt). Separating the two reasons for sentence reductions makes the benefits of pleading guilty more certain, and thus increases the effectiveness of standard plea discounts as inducements to plead guilty. But it also serves to undermine further any claim that guilty pleas are remorseful expressions of the truth of defendants' guilt. The official separation of the guilty plea from remorse as a reason for sentence reduction forms part of a package of reforms (the early plea procedure described above) justified by reference to the public monies saved through reduced trial preparation and investigation, the reduced impact of crimes upon victims, and the benefits to victims and witnesses who then do not have to testify. ${ }^{60}$ All three of these claims are contestable. ${ }^{61}$ However, the more important issue here is whether they increase the pressure on innocent defendants to plead guilty rather than to seek an acquittal at trial. In the introduction to the sentencing guidelines setting out the early guilty plea procedure, it states that: 'The purpose of this guideline is to encourage those who are going to plead guilty to do so as early in the court process as possible. Nothing in the guideline should be used to put pressure on a defendant to plead guilty'. ${ }^{62}$ Whether or not these changes have increased the numbers pleading guilty is a difficult empirical question. Making the discount fixed and clear increases its effectiveness as incentive. But making the maximum sentence discount conditional upon defendants pleading guilty at an earlier time, when they have less disclosure, reduces its attractiveness as an incentive. So, one might well expect fewer defendants to plead guilty where a discount is made conditional

\footnotetext{
${ }^{60}$ Sentencing Council, Reduction in sentence for a guilty plea - first hearing on or after 1 June 2017, supra note 22, 'Key Principles'.

${ }^{61}$ McConville and Marsh argue that late guilty pleas are more attributable to failings by the prosecution, such as late assessment of the strength of the prosecution case resulting in late plea bargaining, rather than any 'gaming' of the criminal justice process that could be remedied by incentives to plead guilty earlier. And whilst trial is an experience that many victims would rather avoid, this is by no means always the case. The trial can give the victim an opportunity to tell their story - to be heard, leading to disappointment when a guilty plea ends this possibility. The claimed saving in private costs (through witnesses not having to appear) is less contentious, but it is not a substantial justification by itself. Criminal Judges: Legitimacy, Courts and State-Induced Guilty Pleas in Britain (Cheltenham: Edward Elgar, 2014), 98-126.

62 Supra note 22, 'Key Principles'.
} 
upon an early plea than would occur in a system that gave the same discount at a later stage. But one can also argue that many defendants faced with this decision at the first Magistrates' Court hearing may be psychologically less well placed to face the risks of a heavier sentence at trial than they would be later in the process. If this is true, then making the maximum discount conditional upon a plea at the early plea procedure will result in more guilty pleas, and the claim that it has increased the pressure to plead guilty is justified. ${ }^{63}$

It is not plausible to deny that innocent defendants will never plead guilty in order to obtain reduced sentences, but in their justifications for changes that increase the various savings that can result from guilty pleas the judiciary have tended to either minimise or ignore this risk. ${ }^{64}$ Defendants are meant to be protected from the 'improper' pressure to plead guilty said to arise when judges indicate

63 'The suggestion that this does not create pressure on at least some cross-section of the defendant population is unconvincing'. E. Johnston and T. Smith, 'The Early Guilty Plea Scheme and the Rising Wave of Managerialism' (2017) 181(13) Criminal Law \& Justice Weekly 210. The Home Office recognised this risk in the White Paper issued following Lord Justice Auld's proposals for a graduated system of sentence discounts adjusted to reward early pleas: 'We do not take lightly the danger of putting defendants under pressure to plead guilty', Justice for All, Cm5563 (2002), para 4.43 , at p.77. In other contexts where people are asked to make an important decision about a possible lost opportunity in response to the first time that the case for it is made to them (e.g. the purchase of a financial investment), there is a widespread acceptance that this is a situation of 'pressure', and regulations commonly provide for 'cooling off' periods.

${ }^{64}$ Quantifying the risk that the incentives for pleading guilty will result in the wrongful conviction of the innocent is difficult, if not impossible. Counting only those cases where a successful appeal establishes the factual innocence of the accused is clearly too small a figure given the restrictions placed on appeals against guilty plea convictions and the Court of Appeal's normal reluctance to declare that those whose convictions are 'unsafe' are actually innocent. Some attempts have been made in the United States to generalise from the numbers exonerated on the basis of new evidence (usually forensic). See S. Gross, 'Convicting the Innocent' (2008) 4 Annual Review of Law and Social Science, 173. Gross found that the false conviction rate for capital murder cases between 1973 and 1989 was $2.3 \%$. He cites a smaller study of cases where murder was accompanied by rape (and semen available for DNA testing) which found an error rate of $5 \%$. There are no figures for guilty plea convictions: 'It is also a fair guess that some of those innocent defendants do plead guilty. But how many? Hundreds a year? Thousands a year? Once again, we don't know.' (at 180) J. Baldwin and M. McConville, in their 1970s study, arranged for the court papers of defendants who had pleaded guilty to be reviewed by a Chief Constable and retired Justices clerk. In one fifth of cases, they concluded that the defendants should not have been advised to plead guilty. Negotiated Justice: Pressures on Defendants to Plead Guilty (London: Martin Robertson, 1977) 75. 
to defendants the different sentences available on pleading guilty and following trial - a protection that has no obvious rationale.

\subsection{Justifications Offered in the Court of Appeal when Determining Convictions as Safe}

Our system, with its reliance on guilty pleas accompanied by sentence discounts, has been criticised for putting considerations of cost and effectiveness ahead of the usual characteristics attributed to trial accuracy in verdicts, and fairness to defendants. Much of this criticism has been directed to our judiciary, as authors of reports recommending reforms, members of the Sentencing Council, and as sitting judges who fail adequately to acknowledge the pressure to plead guilty arising from sentence discounts. ${ }^{65}$ But these developments, in which the judiciary have played a leading role, create particular difficulties for those judges who sit in the Court of Appeal, and have to decide which convictions are safe, and which constitute miscarriages of justice. The actual problem facing these judges is that they cannot use considerations of costs and effectiveness which have led us to our current system of summary or negotiated justice, when articulating reasons why individual convictions should not be quashed. Hence our view that this is an example of what Calabresi and Bobbitt called 'tragic choices'.

Let us consider two recent judicial pronouncements on the nature of guilty pleas. In the Supreme Court in Asiedu in 2016, a terrorist explosives case, Lord Hughes (formerly Vice President of the Criminal Division of the Court of Appeal) refused to allow an appeal against a guilty plea conviction where there had been a serious nondisclosure that might well have resulted in a successful appeal if the conviction had been the result of a trial, on the basis that:

A defendant who pleads guilty is making a formal admission in open court that he is guilty of the offence. ... once he has admitted such facts by an unambiguous and deliberately intended plea of guilty, there cannot then be an appeal against his conviction, for the simple reason that there is nothing unsafe about a conviction based on the defendant's own voluntary confession in open court. $^{66}$

\footnotetext{
${ }^{65}$ McConville and Marsh, supra note 61, offer sustained criticism of our 'criminal judges'.

${ }^{66}$ Asiedu, supra note 47, para 19.
} 
And in R. v Caley in 2012 Lord Justice Hughes (as he then was) defended the practice of reducing the sentence discount for pleading guilty, where defendants delay their decision until their lawyers have full knowledge of the case against them, on the basis that:

... whilst it is perfectly proper for a defendant to require advice from his lawyers on the strength of the evidence (just as he is perfectly entitled to insist on putting the Crown to proof at trial), he does not require it in order to know whether he is guilty or not; he requires it in order to assess the prospects of conviction or acquittal, which is different. ${ }^{67}$

In both of these statements Lords Hughes is insisting that guilty pleas are (at least for the legal processes associated with determining guilt) factually accurate confessions, by the guilty, of the crimes that they have committed. As such, rather than being a suspect form of evidence, something that may even support more liberal rights to appeal than other kinds of process leading to conviction, they are treated as ultra-safe - justifying pleas, for example, obtained in circumstances where defendants may have been unaware of evidence that might be material to their defences.

These statements run contrary to the obvious dangers arising from offering defendants incentives to plead guilty. The attractiveness of these incentives relates to factors that have no evidential value in themselves. Rather they depend on such things as defendants' attitude to risk, or the varied impact that a criminal record or a period of imprisonment will have on them in light of their personal circumstances. ${ }^{68}$ There is also a predictable tension between these statements about guilty pleas, and the manner in which appeal courts approach appeals against conviction following trial. The qualities of fact finding, which the court habitually attributes to a full trial before a jury as part of its routine deference to this form of trial, are absent from guilty plea convictions. Instead, deference has to be directed to the guilty plea, in many respects requiring Lord Hughes (or other appeal court judges) to elevate the evidential status of the plea to a level that compensates for the absence of any substantive review of the evidence. It is difficult to accept that pleas offer such incontrovertible evidence of guilt, even if defendants were not offered sentence discounts as incentives to plead guilty. The ability of defendants

${ }^{67}$ Supra note 43, para 14.

${ }^{68}$ For a fuller account of such arguments, see generally R. Nobles and D. Schiff, 'Criminal Justice Unhinged: The Challenge of Guilty Pleas' (2019) 39(1) Oxford Journal of Legal Studies 100, esp 110-12 for some of the contradictory implications concerning personal circumstances. 
to withdraw confessions made prior to trial, and the need for the probity and reliability of such confessions to be assessed at trials in light of all the surrounding evidence, acknowledges the fallibility of confession as a form of evidence. No matter how formal the circumstances of confessions, and how much legal assistance is provided at the time, judges cannot prevent defendants from giving evidence at trial which contradicts their earlier confessions. Nor could judges direct juries that the contradictory evidence should be given no weight on the basis that the earlier confessions constituted incontrovertible evidence of guilt. And it is worth pointing out the irony of Lord Hughes making such strong claims about the safety of convictions obtained through guilty pleas especially in the particular circumstances of Asiedu. The defendant in that case, at his earlier appeal against sentence, had been described by a different Court of Appeal as 'a liar on an epic scale'. ${ }^{69}$ His guilty plea resulted in a sentence which made him eligible for release on license $231 / 2$ years earlier than his co-defendants. It is hard not to presume that there is little evidential value in a guilty plea entered by an inveterate liar offered this level of inducement to plead guilty. ${ }^{70}$

\subsection{Non-evidential Bases for Restricting Appeals Against Guilty Pleas}

In the Asiedu case Lord Hughes gave additional reasons for finding the conviction safe that did not depend on the evidential value of the plea:

... a defendant who is confronted by a powerful case may have difficult decisions to make whether to admit the offence or not. He will of course be advised that if he does plead guilty that fact will be reflected in sentence, but that general proposition of sentencing law does not alter his freedom of choice in the absence of an improper direct inducement from the judge .... He will always have it made clear to him that a plea of guilty, should he choose to tender it, amounts to a confession.

... the trial process is not a tactical game. A defendant knows the true facts; he ought not to admit to facts which are not true, whatever the evidence against him, and this will always be the advice he is given. If he does admit them, the

\footnotetext{
${ }^{69} R$ v Manfo Kwaku Asiedu [2009] 1 Cr App R (S) 72, para 8 (Sentencing Appeal).

${ }^{70}$ Asiedu was convicted after pleading guilty in advance of what would have been his re-trial, the jury at the previous trial having failed to reach agreement on the charges against him. His co-defendants at the first trial received life sentences with a minimum of 40 years. Asiedu pleaded guilty in exchange for the charges being reduced, a maximum guilty plea discount being applied to the sentence applicable to those charges, and the most favourable version of the facts being used as the basis of sentencing. He received a fixed sentence of 33 years which, with good behaviour in prison, would make him eligible for release after $16 \frac{1}{2}$ years.
} 
evidence that they are true then comes from himself, whatever may be the other evidence advanced by the Crown. ${ }^{71}$

Here Lord Hughes is making claims about the justice of holding defendants to their pleas irrespective of the pleas' evidential value. $\mathrm{He}$ contends that it is fair to hold defendants to the expected consequences of their choices, without regard to the incentives offered for them to exercise their choices in a particular manner; and that innocent defendants who plead guilty are to some extent responsible for their own wrongful convictions. As a justification, perhaps this even assumes that innocent defendants have a moral duty to plead not guilty. Thus, having committed the 'wrong' of pleading guilty when innocent, defendants cannot be allowed to appeal against their own wrongful acts. These claims are clearly problematic. Is it appropriate to allow defendants to choose whether they should be found guilty or not? If the purpose of criminal procedures is to identify the factually guilty, then it is unclear why this factual question should be decided through someone's choice, however free. It is one thing to decide what facts one believes exist by reference to the evidence available, it is quite another to claim that a state of facts exists because someone, even defendants, have chosen to confirm their existence. ${ }^{72}$ Offering someone incentives to choose whether a particular state of facts exists is even less appropriate.

The first statement conflates choice with the fairness of choice. Choices (voluntary selections from alternatives) do not cease to be such just because one is given strong incentives to prefer one choice over another. Although one can speak of 'coercion', 'lack of choice', or 'involuntary choices' when the act of choosing is accompanied by the threat of something which one has a right to avoid, ${ }^{73}$ defendants have

${ }^{71}$ Supra note 47 paras 31 and 32.

72 'The system is meant to ascertain the facts according to the evidence and to assign the punishment proportionate to the crime for the sake of protecting the public. [However] These purposes - truth and justice - cannot be served by a bargaining process.' R. Grant, Strings Attached: Untangling the Ethics of Incentives (Princeton: Princeton University Press, 2012) 101.

${ }^{73}$ Such as an 'improper' inducement or threat. But this, of course, requires a judgement as to what is improper. For an extensive analysis of the kinds of improper action that might render a guilty plea involuntary, see M. Langer, 'Rethinking Plea Bargaining: The Practice and Reform of Prosecutorial Adjudication in American Criminal Procedure' (2006) 33 American Journal of Criminal Law 223. Langer's own examples are discounts offered when the evidence is highly unlikely to secure a conviction at trial; when the sentences authorised by the legislature are excessive, or the charges cover conduct which, though criminal, is socially innocuous. He makes a good moral case for why these practices make a plea involuntary. Treating these 
no right to avoid trial if there is evidence sufficient to ground a charge (a case to answer), and no right not to suffer the appropriate sentence if they are convicted at trial. So, they cannot claim either that the prospect of trial constitutes coercion, or that the offer of a lesser punishment for pleading guilty is coercive. But the fact that someone chooses in full knowledge of what is expected to follow, and without a threat of illegal or immoral consequence, does not tell one whether it is fair or reasonable for them to have had to make that choice, or whether it is unfair or unreasonable for them to seek to undo that choice at a later date. ${ }^{74}$

The second statement comes closest (if accepted) to justifying how the guilty pleas procedures are actually conducted, with defendants required to be formally warned that they should not plead guilty if they are in fact innocent. There are good reasons for such a warning, not least the harm done if those in fact guilty of crimes remain undetected because innocent persons falsely admit to crimes that they did not commit. But whatever wrong is committed by innocent defendants who falsely plead guilty, it is harsh to claim that this wrong is so great that it justifies a general refusal to examine the possibility that they may be innocent. It also seems to be unfair to place responsibility for this wrong solely with the defendant. To use a biblical metaphor, Eve and Adam ate the apple but the serpent encouraged them, the serpent here being the sentence discounts offered to all defendants who plead guilty. The

Footnote 73 continued

practices as grounds of appeal is more problematic. It is difficult for the courts to deny the legislature's authority to criminalize conduct or determine sentences. The remaining practice, accepting pleas where the prosecution evidence is weak, could be reduced if trial judges took a more active role in scrutinising the prosecution evidence prior to accepting a plea, including not treating a confession as corroborating the prosecution case. Appeals could then plausibly be made on the basis that the trial judge failed to recognise the weakness of the prosecution case.

${ }^{74}$ Langer, ibid., questions Langbein's argument that the 'coercion' of sentence discounts for guilty pleas makes them as involuntary as the confessions obtained in Medieval Europe through the use of judicially supervised torture, on the basis that extreme pressure to choose in a particular way does not make a choice involuntary unless the pressure is illegitimate. (J. Langbein, 'Torture and Plea Bargaining' (1978) 46 University of Chicago Law Review 3, at 18) Langer's counter example is a patient who has to choose between death from a medical condition or buying medical treatment. The purchase would still be described as voluntary. But what Langer fails to consider, is that his argument makes the confession after torture in a Medieval court (in the knowledge that the torture will resume if the confession is withdrawn) as voluntary as the contemporary guilty plea, provided only we accept that, applying the standards of the time, the torture, being legal, was legitimate. This points again to the difficulties of seeking to hold people to their choices solely on the basis that they are voluntary. 
harshness of relying on the 'wrong' of falsely admitting guilt to justify refusing to respond in nearly all cases to defendants who attempt to change their pleas at a later date ${ }^{75}$ and restricting their possibilities of appeal, is compounded by the loss of discount faced by defendants who refuse to plea until they have a full sense of the case against them. ${ }^{76}$ And in a case like $A$ siedu, where the defendant decided to plead guilty in ignorance of a significant breach of the prosecution's disclosure obligations, Lord Hughes' approach blames defendants, and in some cases potentially innocent defendants, for decisions that they might not have taken but for wrongs committed by others.

Legal academics have offered other justifications for refusing to give credibility to defendants who wish to appeal their guilty plea convictions. As guilty pleas involve explicit or implicit negotiations they have been likened to the process of settlement within civil proceedings - a mutually beneficial contract which, once agreed, should not be re-opened by parties who later change their minds. ${ }^{77}$ This rationale ignores the crucial difference between civil and criminal proceedings. The community as a whole normally has no independent interest in establishing whether a civil defendant did or did not commit the actions complained of. False convictions, by contrast, impact on the community by removing attention from those actually responsible for crimes, and wasting resources punishing and rehabilitating the wrong persons. ${ }^{78}$ So the state has both an interest in getting convictions right in the first instance and quashing them where mistakes have been made thereafter. Additional weaknesses in the contractual justification lie with the absence, in the treatment of guilty pleas, of any of the factors that allow civil parties to re-open settlement contracts. Misrepresentation, or failure to disclose information that the other party had a duty to provide, would be expected, where

\footnotetext{
${ }^{75}$ The restrictive practice is set out in The Criminal Procedure Rules: The Practice Directions, October 2015 edition, as amended, supra note 26, at 24.10

${ }^{76}$ The requirement to enter a guilty plea at the earliest opportunity in order to obtain the maximum one third discount 'does not depend on the extent of advance information, service of evidence, disclosure of unused material, or the grant of legal aid'. Blackstone's Criminal Practice: 2016 (Oxford: Oxford University Press) D5.27.

${ }^{77}$ See F. Easterbrook, 'Plea Bargaining as Compromise' (1992) 101 Yale Law Journal 1969; Scott and Stunz, supra note 16.

78 'The desire of any court must be to ensure, so far as possible, that only those are punished who are in fact guilty...' S (an infant) v Recorder of Manchester [1971] A.C. 481 at 501 per Lord Morris of Borth-y-Guest.
} 
serious, to allow the disadvantaged party to avoid the settlement contract. ${ }^{79}$ Juliet Horne has discussed whether the judicial treatment of guilty pleas can be justified on the basis that a guilty plea is a delegation of the jury's function to the defendant. ${ }^{80}$ Are defendants' self-assessment, aided by counsel, of the cases against them whereby they convict themselves, ones where they regard the prosecution evidence as sufficiently strong that they would expect a jury to convict? Is this akin to the kinds of self-certification processes that one finds in certain regulatory regimes? This is an interesting rationale but, as she concedes, it cannot explain current practice, as a genuine commitment to an accurate selfassessment would not lead to incentives to form such a judgement at the earliest opportunity. Nor would it justify an inability to alter such selfassessments where evidence had been wrongfully admitted or excluded, or not disclosed.

The weakness of the justifications given for restricting appeals against guilty pleas points to the fact that these normative rationales are not the operative reasons for such restrictive practices. Further evidence of this is provided by developments within both the US and the UK where the use of the plea has developed in a manner which excludes the possibility of some of these rationales, without any lessoning of appeal courts' resistance to appeals against guilty plea convictions. In the US with the development of the Alford plea, ${ }^{81}$ we have a situation in which defendants can plead guilty and earn their sentence discounts, whilst still asserting their innocence. This removes any possibility of treating guilty plea convictions as evidence of guilt, or expressions of remorse, or factual evidence that has misled the court. The court is left solely with the status of such pleas as waivers of rights of appeal - an act that defendants have chosen voluntarily to make in the knowledge of the consequences, and this has to stand alone as a justification for the

\footnotetext{
${ }^{79}$ The gradual loss of discount does not contradict the comparison with civil proceedings. It is open to civil law defendants to structure their offers as progressively smaller sums the further the case proceeds: ' $£ 100,00$ if you settle pre-discovery, $£ 50,000$ if we have to go through discovery', etc.

${ }^{80}$ See Horne, supra note 20.

${ }^{81}$ North Carolina v Alford, 400 U.S. 25 (1970).
} 
refusal to allow appeals against conviction. ${ }^{82}$ In the UK, the equivalent of Alford pleas occur when defendants plead guilty whilst still insisting to their counsel that they are innocent. In $R v$ Dann $^{83}$ the defendant accompanied his plea with a signed statement declaring that he was not guilty and was only pleading guilty in response to an offer not to prosecute his wife if he did. On appeal, the statement was held to make no difference to the 'unequivocal' nature of his plea, and the restrictions on appeal which followed, although there was no claim in this case that the plea itself was evidence of the defendant's guilt. ${ }^{84}$ Thus the difference here between the US and the UK is more a matter of form than substance - in the US the trial court is made aware of the claim of innocence at the time of the guilty plea, whilst in the UK this knowledge remains with defendants' counsel.

\subsection{Ongoing Reasons for the Resistance to Guilty Plea Appeals - Back to Workable Relationships?}

It is difficult to quantify the increased workload that could arise if the Court of Appeal adopted a more liberal attitude towards appeals against convictions based on guilty pleas. However, we can consider some figures that give a sense of the size of the problem. For example, the Court of Appeal heard 215 conviction appeals in 2016-17. ${ }^{85}$ Given the restricted grounds for appealing guilty pleas, we can assume that few if any of these appeals followed guilty pleas. In 201617 the CPS obtained convictions through trial in 7,806 cases, some $8.80 \%$ of convictions $(61,808$ guilty pleas were $70.10 \%$ of overall convictions). ${ }^{86}$ As 215 cases were appealed, there was an appeal rate in relation to convictions after trial (relying on our assumption that

\footnotetext{
${ }^{82}$ See, S. Schneider,' When Innocent Defendants Falsely Confess: Analyzing the Ramifications of Entering Alford Pleas in the Context of the Burgeoning Innocence Movement' (2013) 103 Journal of Criminal Law \& Criminology 279. The introduction of such pleas in the UK might lead to more guilty pleas - as defendants may feel that they will suffer less reputational damage from conviction if they can maintain the claim of innocence.

83 [2015] EWCA Crim 390.

${ }^{84}$ See also $R$ v Herbert (1992) 94 Cr. App. R. 230 where, in similar circumstances to Dann, a defendant pleaded guilty 'whilst maintaining his innocence'.

${ }^{85}$ Court of Appeal (Criminal Division) Annual Report 2016-17, Annex C.https:// www.judiciary.uk/publications/court-of-appeal-criminal-division-annual-report2016-17/.

${ }^{86}$ CPS crown court outcomes 2014-17. https://www.CPS.gov.uk/underlying-data/ CPS-crown-court-outcomes-2014-2017.
} 
there were very few guilty plea appeals) of $2.75 \%$. Although of course one would expect it to be considerably less, if the same appeal rate occurred with their guilty plea convictions the Court of Appeal would have to hear nearly an extra 1,700 cases. This would represent approaching an eight-fold increase in the Court's workload. In addition, there would be an increase in the workload of the Crown Courts, who would have to conduct trials originally avoided through the plea. If the current statutory bar against appeals from Magistrates' Courts guilty plea convictions were removed, there is a similar potential for a huge increase in the appeal workload of the Crown Court. In 2018 there were 4,737 appeals against conviction heard in the Crown Courts. ${ }^{87} \mathrm{We}$ assume that few of these would have involved guilty pleas. ${ }^{88}$ To get a rough sense of the appeal rate applicable, we can look again at the 2016-17 CPS figures, this time for convictions in the Magistrates' Courts following trial: $28,424{ }^{89}$ If 4,737 is treated as the number of appeals from CPS convictions at trial in 2016-17 it would represent an appeal rate of $16.67 \%$. There were 390,344 convictions following guilty pleas in the Magistrates' Court in 2016. If $16.7 \%$ of these were appealed this would generate over 65,080 appeals! This is, of course, quite unrealistic in many respects. Nevertheless, these figures illustrate what we already know the dependence of our criminal justice system on guilty pleas at trial level creates a situation in which granting any increased rights of appeal to those who have pleaded guilty could be extremely costly. ${ }^{90}$

The difficulties of allowing appeals against guilty plea convictions is not simply a matter of numbers. The immediate problem in almost every case is the lack of a transcript of evidence. ${ }^{91}$ With appeals against convictions following trial, the Court of Appeal, or other appeal body, assesses the significance of any procedural error, or new

\footnotetext{
${ }^{87}$ As set out in the tables at: https://assets.publishing.service.gov.uk/government/ uploads/system/uploads/attachment_data/file/790161/ccsq-tables-q4-2018.ods.

${ }^{88}$ Magistrates Courts Act 1980, s.108.

${ }^{89}$ As set out in their 2018-19 report, at p. 22: https://www.CPS.gov.uk/sites/ default/files/documents/publications/CPS-Annual-Report-and-Accounts-2018-19. pdf.

90 The higher rate of appeal against conviction at trial by Magistrates' compared with Crown Courts reflects the unrestricted (except by time limits) right to a complete re-hearing. Would it continue to be unrestricted, and how would this operate, if guilty plea convictions could also be appealed?

${ }^{91}$ However, in cases where the guilty plea was entered at a re-trial, there will be a transcript of the first trial.
} 
evidence, in light of the whole of the evidence. Where evidence is disputed, they assume that the jury accepted the prosecution's version of events and are reluctant to form a different view (hence the accusation of undue deference to juries). This method is not open to them with guilty pleas. The Court cannot rely on a prior assessment of the evidence. It must form its own view of the prior evidence and, in most cases, this will only be the evidence disclosed to the defence up to the moment when the guilty plea was entered. This also goes some way to explain the appeal court's reluctance to consider new evidence. Being unable to assess the new evidence in light of the evidence presented at trial, it has little against which to balance that evidence when considering the safety of the conviction. Evidence which, by itself, shows that the defendant could not have committed the crime does not require any weighing. But, as the extensive case law on the right to compensation following successful appeals against conviction has consistently recognised, one rarely encounters new evidence that establishes beyond any reasonable doubt that a defendant could not have committed the offence in question. ${ }^{92}$

As well as the difficulties of hearing guilty plea appeals, there are also difficulties with any possible remedy. If the Court of Appeal decides that a guilty plea conviction is unsafe it must either quash the conviction per se or quash the conviction and order a trial/re-trial. The latter outcome raises all the issues which currently bedevil the Court when considering whether to order re-trials. The longer the delay between a conviction and the order for retrial, the less likely it is that the trial will be either fair or effective. Witnesses forget, move and die. Where this undermines the prosecution case one has the prospect of defendants being acquitted due to lack of formerly available evidence. Where the deterioration affects defendants' cases, we have the prospect of 're-trials' that will appear unfair in light of evidence, or potentially exclusionary evidence, no longer available. The absence of a trial transcript also reduces the Court's ability to impose alternative convictions rather than sustain convictions. This power arises following successful appeals from convictions following either trial or a guilty plea. ${ }^{93}$ But in the case of early guilty plea convictions there will have been no articulation or exploration of the

${ }^{92} R$ (on the application of Adams) v Secretary of State for Justice [2011] UKSC 18; Allen $v$ United Kingdom (2016) 63 E.H.R.R. 10; $R$ (on the application of Hallam) $v$ Secretary of State for Justice [2019] UKSC 2.

${ }^{93}$ Criminal Appeal Act 1968, s3,3A (as substituted by the Criminal Justice Act 2003 ss.316(3), 336(3)(4). 
defence case, making it difficult to justify alternative offences, particularly as the court is unable to rely on the plea as evidence of guilt.

The resources and law and order implications of increasing the right to appeal guilty plea convictions rarely, if ever, feature in Court of Appeal judgments. Instead we find statements like those of Lord Hughes which, as we have tried to illustrate, are not dissimilar from the statements of other senior judicial figures over one hundred years earlier in their adamant opposition to the setting up of a Court of Criminal Appeal. Hence our view that these statements are an example of tragic choices - the use of value reasoning to defend institutional arrangements put in place for other reasons, particularly those of cost and efficiency. However, one should not interpret the absence of an express discussion of these factors and the attempt to justify guilty plea convictions on the basis of ideas of truth and moral wrongdoing as no more than a judicial smokescreen. There are other reasons why these considerations of cost and efficiency would not feature in the discourse of any Court of Appeal. The Court's role is to distinguish safe from unsafe convictions. It is not open to the Court to identify the number of appeals that it believes the Court could manage, and pronounce the applications made next in time as automatically 'safe'. In this the Court of Appeal is no different from any other court. It has to treat like cases alike. As such, the discourse through which it rations access to itself and the courts which it supervises has to be based on distinctions which it can draw, and justify, between convictions which it finds safe, and those it finds unsafe. In constructing its reasons for finding guilty plea convictions safe, it has to draw upon the same discourse of truth, and rights, with which it constructs safe and unsafe convictions on appeals from trials. Whether judges convince themselves of the justice of their current treatment of guilty pleas is an open question. But from an external perspective, the attempt to justify a near blanket ban on guilty plea convictions has echoes of the 19th century judicial resistance to any appeals against jury verdicts except on points of law, as expressed by Baron Parke in the quote at the start of this article - a view which, if our system ever evolves in a manner that dispenses with guilty pleas, may be viewed as sanguine, if not smug complacency. 


\section{PART FOUR: MOVING ON FROM THE CURRENT POSITION?}

There is little evidence that our recent dependence on guilty pleas is going to lessen in the near future. A proposal to increase sentence discounts for guilty pleas (from one third to one half) was made as recently as $2010 .{ }^{94}$ This proposal was not shelved because of its effect on the potential safety of convictions, but principally because the government felt that it might result in sentences, particularly for sex crimes, that the public would regard as too lenient. ${ }^{95}$ The CPS are committed to maintaining or increasing the percentage of convictions obtained through guilty pleas at the first crown court hearing, as evidenced by their selection of this as a performance indicator. ${ }^{96}$ The Ministry of Justice declines to set a target for guilty pleas, as this 'could discourage prosecution of hard-to-prosecute cases or encourage unreasonable pressure on defendants to plead guilty early'. ${ }^{97}$ But at the same time, it treats avoiding cracked trials as one of the primary measures of its own efficiency. As four out of five cracked trials are the result of defendants entering late changes of plea, encouraging more defendants to enter early guilty pleas will demonstrate the Ministry's increased efficiency. ${ }^{98}$

Meanwhile, those who draw attention to the potential for real injustices associated with guilty plea convictions have great difficulty in advocating their diminishing, in light of the cost of offering trials to many of those persons currently pleading guilty. Campbell, Ashworth and Redmayne, who criticise guilty pleas for their failure to provide

\footnotetext{
${ }^{94}$ Ministry of Justice (Cm 7972), Breaking the Cycle: Effective Punishment, Rehabilitation and Sentencing of Offenders.

95 J. Roberts and B. Bradford, 'Sentence Reductions for a Guilty Plea in England and Wales: Exploring New Empirical Trends' (2015) 12 Journal of Empirical Legal Studies 187, at 189.

96 CPS Annual report 2018-9, supra note 15, p. 11.

${ }^{97}$ National Audit Office (NAO), Ministry of Justice: Efficiency in the Criminal Justice System, HC 852 Session 2015-16 1 March 2016, Part 1, p. 17.

98 The NAO, ibid., noted that between 2011 and 2015 there were fewer cracked trials (down from $30 \%$ to $24 \%$ ) and more trials being vacated (up from $24 \%$ to $33 \%$ ). They concluded that this 'suggests that the system is getting better at identifying where cases are likely to crack and removing them from the list before trial.' ibid., p. 17. It is unclear how or why court staff would become better at identifying which cases listed for trial would end in guilty pleas. The more likely explanation for these figures is that fewer defendants left it until their trials to change their plea to guilty.
} 
the same assurances of accuracy and fairness as come with trial, question whether we could afford even to review prosecution evidence in guilty plea cases without some compensating reduction in the resources needed to try those who plead not guilty. Their argument is principally directed to the level of discounts that should be available, proposing a limit of $10 \%$ on the sentence reduction offered for pleading guilty. ${ }^{99}$ McConville and Marsh question the effectiveness of sentence discounts, relying on a Canadian study which concluded that $70 \%$ of those who plead guilty might still be expected to do so without any reduction in sentence. ${ }^{100}$ They similarly question the need for sentence discounts to reduce progressively in order to save the costs of 'cracked' trials. ${ }^{101}$ Reducing the levels of sentence discount reduces the incentives for defendants to plead guilty, and increases the plausibility of judicial claims that guilty pleas offer a safe basis for convictions. However, unless the reduction in the size of discounts was accompanied by a reduction in the sentences normally imposed after conviction at trial, it would result in a significant increase in the prison population. ${ }^{102}$ In addition, any claim that a fixed percentage reduction in the automatic discount for pleading guilty would make such convictions safe needs to take account of the factors that will alter the impact of that reduction: the ability to choose lesser charges, and the ability to agree facts which minimise the severity of the offence, and the choice of whether to charge persons close to the defendant.

Should we seek to protect those persons who might be more vulnerable to the pressure to plead guilty when innocent? ${ }^{103}$ This

${ }^{99}$ L. Campbell, A. Ashworth and M. Redmayne, The Criminal Process (Oxford: Oxford University Press, 2019), ch. 10, especially 'Conclusion' at 10.8 and p. 341.

${ }^{100}$ McConville and Marsh, supra note 61, p.112.

101 Though they rely on the Runciman Royal Commission's estimate of the percentage of 'cracked' trails caused by late changes of plea, which conflicts with the much higher NAO more current estimate.

102 The Justice Select Committee, in their Report on the proposed reduction in sentence discounts for failure to plead at the earliest opportunity, estimated that this change might increase the prison population by between 1,000 and 4,000. See Justice Select Committee Report, Reduction in Sentence for a Guilty Plea Guideline. para 11, available at http://www.publications.parliament.uk/pa/cm201617/cmselect/ cmjust/168/16802.htm.

${ }^{103}$ See, for example, J. Peay and E. Player, 'Pleading Guilty: Why Vulnerability Matters' (2018) 81 Modern Law Review 929; R. Helm, 'Conviction by Consent? Vulnerability, Autonomy and Conviction by Guilty Plea', (2019) 83 The Journal of Criminal Law 161. 
raises problems of identifying vulnerability. Vulnerability may arise from the general capacity of the individual (as with mental illness), or their personal circumstances, as with those who cannot afford the financial costs of their defence, or have employment, business or family responsibilities that make it imperative for them to avoid or reduce their period of custody. It may also arise from the particular circumstances of the offence, as occurs when the defendant lies on the cusp of a prison sentence and therefore may be able to avoid custody through pleading guilty. ${ }^{104}$ Or it may arise through a combination of factors. Alongside the issues of identifying who is to be considered vulnerable, one has to consider at what point in the process this element of vulnerability should be identified, and what protection should be afforded? Since the plea crucially affects the procedures that follow, this assessment needs to be made prior to the decision to plead. If the guilty pleas of the unidentified vulnerable are void or voidable, one faces the prospect of having later to restart procedures and processes of preparing for trial which, with sufficient delay, may no longer be possible.

If procedures could be put in place which identified the vulnerable, what response is appropriate? Simply to exclude them from the ability to plead guilty and require them to face a trial would, without further adjustment, result in those who were convicted at trial spending longer in prison than more 'able' defendants who had been allowed to plead guilty and receive their discounted sentences. So, if vulnerability were identified by reference to factors such as disability, socioeconomic status, or ethnic group, the advantages of greater certainty that their convictions were justified by the evidence would have to be weighed against the increase in penalties that this group would on average face compared with other persons who are convicted of the same crimes, but have been able to plead guilty and achieve reductions in their sentences. ${ }^{105}$ One could avoid this consequence by allowing the vulnerable who opt for trial to obtain the same discounts as the able who plead guilty. This would be controversial, as the

${ }^{104}$ For an argument against using guilty plea reductions in situations where one escapes custody by plea - where the pressure to plead guilty is acute - see J. Robert and L. Harris, 'Reconceptualising the Custody Threshold in England and Wales' (2017) 28 Criminal Law Forum 477.

${ }^{105}$ Roger Hood found that suspects from an Afro-Caribbean background tend to plead not guilty more frequently than others and, when convicted, tend to receive longer sentences largely because they have forfeited the discount for pleading guilty: Race and Sentencing: a Study in the Crown Court (Oxford: Clarendon Press, 1992) 125. 
justifications given for discounts (costs saved, witnesses and victims spared from having to testify, etc.) would be absent in such cases. The current adjustment for the vulnerable is restricted to circumstances where it is unreasonable for them to enter a guilty plea at the earliest opportunity, in which case they may still receive the full discount for a late plea. The focus of this exception (and the only specific example provided in the guidelines) is a person who fails to understand that the acts they are accused of committing constitute a criminal offence. ${ }^{106}$ The guidelines expressly distinguish between failing to understand that an offence has been committed (where delay in entering a plea will be excused) and failing to understand the strength of the prosecution case (where it will not). ${ }^{107}$ This exception does not seek to protect those who, for reasons of mental capacity or external pressures, might be particularly inclined to plead guilty despite innocence in order to reduce the severity of their sentence.

In a discussion of the possibilities for change, one needs also to take account of the presence or absence of pressure for reform from outside the legal system, most notably from the mass media and the political system. Public confidence in the criminal justice system is a recognised pre-condition to its efficient operation, and miscarriages of justice have been credited, within both the media and Parliament, as something that can undermine that confidence. The media reports on miscarriages in terms of the factual innocence of those convicted, whereas, as recently emphasised by Baroness Hale: "Innocence as such is not a concept known to our criminal justice system". ${ }^{108}$ Miscarriages are constructed within our legal system in terms of errors of procedure or new evidence which, had the former not occurred or the latter been available, might have made a difference to the verdict (guilty or not guilty) in a criminal trial. By contrast, the media focus on a person's factual innocence, and in consequence one

106 'Where the sentencing court is satisfied that there were particular circumstances which significantly reduced the defendant's ability to understand what was alleged or otherwise made it unreasonable to expect the defendant to indicate a guilty plea sooner than was done, a reduction of one-third should still be made'. Sentencing Council, supra note 22, Principle F1.

107 'In considering whether this exception applies, sentencers should distinguish between cases in which it is necessary to receive advice and/or have sight of evidence in order to understand whether the defendant is in fact and law guilty of the offence(s) charged, and cases in which a defendant merely delays guilty plea(s) in order to assess the strength of the prosecution evidence and the prospects of conviction or acquittal.' ibid.

108 Adams, supra note 92, para 116. 
might have expected this media focus to provide a basis for critical reporting of guilty plea convictions. ${ }^{109}$ After all, it is not difficult to understand that significant sentence reductions offered in exchange for guilty pleas represent a pressure to plead guilty that can be expected to influence at least some innocent defendants to plead guilty. But there appears to be no general dissatisfaction within the media over convictions obtained through guilty pleas. Indeed, one of the factors normally required before the media give credence to claims of wrongful (factually innocent) conviction is that the person involved continues to proclaim their innocence. Whilst confessions obtained in custody and subsequently retracted are no longer given the status that they formerly had, pleading guilty provides a formidable obstacle to mounting a press story (let alone a media campaign) that a factually innocent person has been wrongfully convicted.

Another factor that inhibits media pressure for change in the treatment of guilty pleas is the role played by the CCRC. ${ }^{110}$ Prior to 1997 there was no procedure which could quash a conviction obtained through a guilty plea in the Magistrates' Court. Where evidence emerged that exonerated the defendant the only procedure open to them was to seek a pardon. Since the CCRC began operating in that year there is now a process by which any Magistrates' Court conviction which the media regard as unsafe (which for the media invariably translates as a factually innocent defendant) could be re-

${ }^{109}$ For extended analysis of the difference between media reporting of convictions and their status within legal discourse, see R. Nobles and D. Schiff, supra note 2, ch 4.

110 'The media have become uninterested in publishing reports about miscarriages of justice, primarily because they appreciate that their reports would be followed not by administrative action but, seemingly, by inertia. Cases now spend years hidden from public scrutiny while they are examined by the CCRC'. Bob Woffinden's written evidence to the House of Commons Justice Select Committee in 2014, para 33. http://data. parliament.uk/WrittenEvidence/CommitteeEvidence.svc/EvidenceDocument/Justice/ CriminalC $\%$ CC $\% 88$ asesR $\%$ CC $\% 88$ eviewC $\%$ CC $\% 88$ ommission/written $/ 16131 . h t m l$ Bob Woffinden was, until his untimely death in 2018, an investigative journalist who wrote a large number of books on notorious miscarriages of justice, their notoriety in many ways due to his extraordinary journalistic endeavours. "A result of [the advent of the CCRC] was to keep things out of the media ... somewhere along the line a lot of journalists have got the message that these things are being dealt with."' (Interview with a journalist, D. Eady, Miscarriages of Justice: The Uncertainty Principle, PhD Thesis, Cardiff University, July 2009, p. 275. https://orca.cf.ac.uk/54837/1/U585226.pdf. 
viewed by the Crown Court, following application to the CCRC and referral. ${ }^{111}$ With Crown Court convictions, the Court of Appeal's resistance to reconsidering guilty plea convictions is compensated for, to a limited extent, by the CCRC's right to refer guilty plea cases. However, in view of their statutory authority, the CCRC can only refer cases where there is a 'real possibility' of success, which requires it to take account of the restrictions which the Court of Appeal has placed upon guilty plea conviction appeals. This severely limits its ability to operate as a means to rectify potential wrongful (both in terms of factual innocence and breaches of rights) convictions arising from guilty pleas. Nevertheless, the CCRC offers a mechanism whereby cases which may have gained media attention can be reexamined by the Court of Appeal, even in guilty plea cases. Such referrals may deflect media criticism of potentially unremedied miscarriages and the demands for reform which might accompany these, and they do not require referral of a large number of cases to achieve this. Only a small percentage of those who had pleaded guilty apply to the CCRC to have their convictions reviewed. In her study of guilty plea applications to the CCRC over a twelve-month period Juliet Horne identified 235 such cases. ${ }^{112}$ This is a significant per-

${ }^{111}$ Kerrigan has argued that the CCRC's power to refer appeals to the Crown Court under the Criminal Appeal Act 1995 s.11 must apply a 'real possibility' test that anticipates the result of a complete re-hearing under the Magistrates Court 1980 s.108. This means that the CCRC should be able to refer any case where the prosecution will not be able to demonstrate, beyond a reasonable doubt, that the defendant is guilty, provided only that the defendant raises an argument or evidence not previously raised. As there will have been no trial, this would make summary guilty plea convictions open to referral whenever the limited record of prosecution evidence showed something less than overwhelming evidence of guilt. (K. Kerrigan, 'Miscarriage of justice in the magistrates' court: the forgotten power of the Criminal Cases Review Commission' [2006] Criminal Law Review 124).

112 In her study of the CCRC, Juliet Horne sampled cases received by the CCRC in 3 four-month periods between September 1, 2011 and April 30, 2013. She identified 281 applications for review of convictions following guilty pleas (see Horne, supra note 20, pp. 251-2, footnotes 749 and 750) - although amending the figures to represent a fair assessment, it was clear that guilty plea applications were more than $20 \%$ of applications. That said it needs to be remembered that conviction following plea is so much more common than following trial. Her findings are supported in the latest extended research into the work of the CCRC by C. Hoyle and M. Sato, Reasons to Doubt: Wrongful Convictions and the Criminal Cases Review Commission (Oxford: Oxford University Press, 2019). They show how one set of guilty plea convictions have now been overturned in one specific field - that of immigration and asylum law. But in other guilty plea applications the 'CCRC's approach to guilty pleas is clearly influenced by the Court' and that (for some Commissioners at least) 'a 
centage of the applications to the CCRC (21\%), but a very small number relative to the number of annual guilty plea convictions. Only a tiny number of these applications resulted in a referral to the Court of Appeal for a review of conviction. For the first sixteen years of their existence only 49 guilty plea convictions were referred by the CCRC for a review of their safety. ${ }^{113}$ This is a manageable number of extra appeals. In effect, the CCRC operates as a gatekeeper, identifying exceptional cases where the available evidence provides a powerful indication of innocence despite the guilty plea. Whilst the CCRC have never limited themselves to cases which find support in the mass media, the Commission plays an important role in offering a means by which such cases can be investigated by a body which is regarded as impartial. As with miscarriages arising from trial, these investigations reduce the likelihood that individual cases will be reported in the press in terms of systemic failings and, as such, depress the pressure for reform.

\section{SUMMARY}

We have attempted to show that the judicial treatment of appeals against conviction following a guilty plea is an example of tragic choice - the need to justify procedures by reference to values such as rights and truth, and without reference to the considerations (cost, efficiency, crime control etc.) which have led to their introduction. Tragic choice is present when judges seek to justify convictions following trial, but this is heightened in guilty plea cases. This is not just a result of the far larger number of convictions that arise from pleas rather than trials. When it comes to guilty pleas, the court has to

\section{Footnote 112 continued}

guilty plea is synonymous with a confession of guilt, rather than a tactical approach to securing a reduced sentence or product of poor legal advice' (at pp. 106 and 107). Following Horne's research evidence, they recognise how guilty plea cases tend to be screened out "through "a highly abbreviated process", thus risking "overlooking meritorious cases".' (p. 108) The problem remains as to how, and when, other sets of guilty plea convictions demonstrating a pattern of fallibility will come to the CCRC and/or Court's attention and cause them to re-examine their general approach.

113 The success rate in these appeals following referral is however higher than in other cases, with 39 of these 49 referrals resulting in the conviction being quashed. (Horne, ibid., p. 252). Again, the detailed evidence suggests particular reasons for this that do not detract from the CCRC or Court's general approach to guilty plea applications and appeals - in other words, specific issues were involved that are not generalisable - see Hoyle and Sato, ibid., pp. 107-8. 
attribute the same values (truth and rights) to the conviction that follows a plea as it attributes to a conviction following trial, but without the benefit of the features of trial which help to make that attribution plausible (lay judgement, hearing witnesses, cross-examination, etc.) Recent changes to the plea system (in the interests of efficiency) such as restricting maximum sentence discounts to pleas made at the earliest opportunity, further distance guilty pleas from the protections afforded by trial, and compound the difficulties in justifying these convictions as 'safe'.

Guilty pleas also offer the judges little scope for identifying or remedying errors, as there is no transcript of evidence to review, or a basis to substitute alternate convictions. A general willingness to allow appeals against guilty plea convictions could not only lead to a large increase in the number of trials but, without a strict time limit on the right to appeal, would lead to trials which repeat all the difficulties of ordering fair re-trials long after the original investigation. In the face of these difficulties, the courts have placed the strictest of limitations on appeals, basically restricting them to circumstances where appellants are able to show that they did not intend to admit to facts that constituted the offense for which they were convicted. Even circumstances that would ordinarily justify an appeal against a trial conviction, such as significant non-disclosure or plausible and probative new evidence can only exceptionally justify a successful appeal against a guilty plea conviction. Thus, we have a situation in which a procedure which, on its face is less capable of identifying guilt than a trial, has to be defended on the basis that it is overwhelmingly more capable of identifying guilt (or so fair as to justify disregarding the possibility of innocence). The criminal justice system for England and Wales has, since 1907, had an institutional means to recognise the undeniable possibility that trials can in a small (relative to its critic's beliefs) but significant number of cases perpetrate miscarriages of justice. But with guilty pleas we have, for reasons of cost and efficiency, reached a situation where the Court of Appeal cannot provide a remedy for miscarriages, and must instead, like the judges of the 19th century, claim the relevant procedures are so safe that there is little or no need for review, even in cases of procedural irregularity (short of abuse of process) or new evidence (short of exoneration). At present, there is no reason to think that this situation will be ameliorated, 


\section{CONCLUSION}

Different pre-trial and trial procedures as they have evolved, whether through slow evolution or more abrupt legislative change, can be shown to throw up different potential for miscarriages of justice ${ }^{114}$ and, at the same time, different challenges for appeal practices, procedures and doctrine. The appeals process is the place within the criminal justice system where claims that our procedures for obtaining convictions are based on acceptable values (truth, rights, fairness, etc.) are most in evidence and, at the same time, most exposed. As the practices of the criminal justice system evolve, the procedures which have to be justified when defendants appeal alter. While tragic choice is, we would argue, a constant feature underlying the justifications offered in criminal appeals, what has to be justified by the appeal courts is not constant. There are obvious parallels between the reliance on conviction through incentivised guilty pleas, and reliance on convictions obtained through 'coerced' confession evidence. ${ }^{115}$ The latter has undergone a process of change, with the opportunities for such coerced confessions reduced through the reforms introduced by the Police and Criminal Evidence Act 1984, and the need to rely on them diminished through the increased availability of new forms of forensic evidence (DNA, CCTV, etc). These changes alter what is 'normal' at trial, and what needs to be justified on appeal. That said, our current reliance on guilty pleas is such that it is difficult to see what changes are going to relieve the judiciary from having to make the strong claims for their evidential value and fairness which they are currently making. In so doing, and thereby refusing to re-examine guilty plea convictions in many, if not most, circumstances, they expose themselves to accusations that they have been, and continue to be, indifferent to justice, or at least sanguine about the improbability of its miscarriage.

${ }^{114}$ See R. Nobles and D. Schiff, 'Trials and Miscarriages: An Evolutionary SocioHistorical Analysis' (2018) 29 Criminal Law Forum 167.

${ }^{115}$ We use the phrase 'coerced' confession evidence as shorthand for the range of pre-trial practices that no longer live up to our standards, whether concerning oppressive or even brutal police questioning at one end of the spectrum, to techniques involving suggestibility on the other. 


\section{OPEN ACCESS}

This article is licensed under a Creative Commons Attribution 4.0 International License, which permits use, sharing, adaptation, distribution and reproduction in any medium or format, as long as you give appropriate credit to the original author(s) and the source, provide a link to the Creative Commons licence, and indicate if changes were made. The images or other third party material in this article are included in the article's Creative Commons licence, unless indicated otherwise in a credit line to the material. If material is not included in the article's Creative Commons licence and your intended use is not permitted by statutory regulation or exceeds the permitted use, you will need to obtain permission directly from the copyright holder. To view a copy of this licence, visit http://creativecommons. org/licenses/by/4.0/.

Publisher's Note Springer Nature remains neutral with regard to jurisdictional claims in published maps and institutional affiliations. 